\title{
Об одном инвариантном мотиве движения в поэтике В. М. Шукшина
}

\author{
П. С. ГЛУШАКОВ \\ 4 Kandavas iela, Kurzemes priekšpilsēta, LV-1083 Rīga \\ E-mail: glushakovp@mail.ru
}

(Received: 15 July 2016; accepted: 30 September 2016)

\begin{abstract}
This paper focuses on Vasily Shukshin's "working records" dated from 1966. It is established that a lot of contexts and names are important for the interpretation of these records: from the antique myths to Russian literature. In the paper, it is proved that the motive of the waterway of a ship appears in Shukshin's texts as the concentrated symbol of spiritual aspirations, warm rushes, as the allegory of movement towards the aim and the overcoming of obstacles. At the same time, it is also a symbol of moral ascension, which is shown by the reflections about intelligence as the aim of the artist. The conclusion drawn is that the poetics of Vasily Shukshin's texts represents a very open and dialogical structure with wide referential installations.
\end{abstract}

Keywords: semantics, poetics, text interpretation, context, Vasily Shukshin

«Нет, ребята, „могучей кучки“ не получилось. Жаль»

«Не теперь, нет. Важно прорваться в будущую Россию»

«Мы с вами распустили нацию. Теперь предстоит тяжелый труд - собрать ее заново. Собрать нацию гораздо сложнее, чем распустить»

(Василий Шукшин: «Рабочие записи»)

В. М. Шукшин не оставил развернутых «теоретических» текстов, по которым можно было бы судить о его концепции истории русской литературы (культуры), но между тем, следуя за поэтической логикой произведений писателя, можно попытаться реконструировать некоторые смысловые элементы подобной непроявившейся в целостности, «зашифрованной» (по собственному же признанию прозаика ${ }^{1}$ в наименее публичной и, как можно предполагать, максимально откровенной форме рабочих записей.

Размышления Шукшина, как правило, укладываются в обычную трехэлементную модель: предшествующее - переломное - чаемое, где первый элемент дан в «давнопрошедшем» времени, второй подается в координатах

${ }^{1}$ Ср., например: «Вообще говоря, вырисовывается как будто и теорийка: „Смещение акцентов“. Главное (главную мысль, радость, боль, сострадание) - не акцентировать, давать вровень с неглавным. Но - умело давать. Работать под наив» (Шукшин 1996: 227). 
современности (впрочем, понимаемой как культурная современность, «от Пушкина до наших дней»), а третий элемент еще не проявленное будущее, «пучок возможностей». Как можно убедиться, такая формула уже сама по себе строится как метафора движения (пути, путешествия) от некого состояния к другому через катаклизм или, по крайней мере, преодоление препятствия. В отличие от основной мифологемы писателей-традиционистов, Шукшин совершенно не интересуется первым этапом (элементом) своей трехчастной модели: для него начальный этап разворачивающейся картины движения почти не окрашен в тона «потерянного рая» («лада» народной жизни, «России, которой мы потеряли» и пр.); здесь писатель подчеркивает только огромное напряжение, с которым придано «ускорение» метафорического движения ${ }^{2}$ (наиболее частотное здесь слово «работа» и производные от него). Катастрофа (переломное событие) не имеет исторической приуроченности (конечно, в устных характеристиках, по воспоминаниям современников, Шукшин мог называть ключевые, по его мнению, точки распада - церковный раскол XVII века, октябрь 1917 г., «год великого перелома» 1929 г., например); писатель выстраивает свое понимание такого процесса: «Произведение искусства - это когда что-то случилось: в стране, с человеком, в твоей судьбе» (Шукшин 1996: 219). Будущее (опять-таки в противоположность установкам традиционистов) для Шукшина не есть возвращение в прошлое, оно открыто, «пункт назначения» не предопределен; именно потому «важно прорваться в будущую Россию», а не в будущеее России. ${ }^{3}$

В известной статье «Монолог на лестнице» (в самом заглавии которой заложены амбивалентные варианты прочтения: восхождение вверх или спуск вниз) содержится следующее признание:

Так у меня вышло к сорока годам, что я - ни городской до конца, ни деревенский уже. Ужасно неудобное положение. Это даже - не между двух стульев, а скорее так: одна нога на берегу, другая в лодке. И не плыть нельзя, и плыть вроде как страшновато. Долго в таком состоянии пребывать нельзя, я знаю упадешь. Не падения страшусь (какое падение? откуда?) - очень уж, действительно, неудобно. Но и в этом моем положении есть свои «плюсы» (захотелось вдруг написать - флюсы). От сравнений, от всяческих «оттуда - сюда» и «отсюда - туда» невольно приходят мысли не только о «деревне» и о «городе» о России (Шукшин 1996: 48).

Здесь Шукшин преодолевает драматическую заданность извечной коллизии русской культурной ситуации - выбора между двумя вариантами развития. Статика и движение, твердь и водная стихия объединены у писателя

${ }^{2}$ Образ баржи (корабля) в прозе писателей традиционной школы, насколько можно судить, не выходил за рамки простого сравнения, поданного в регистрах народно-иронический сниженной традиции: «Грудина, а ноги-то, девка что баржа» (В. Белов: Привычное дело).

${ }^{3}$ Для понимания писателем движения как такового важны, например, такие размышления: «Общество распределяет силы: тех, что впереди, на передовых рубежах, поддерживаю те, что сзади. На равных. Неразумно бросать всех сразу вперед» (Шукшин 1996: 46). 
сдерживающим единством: он готов покинуть родной берег, но не может отправиться в водное путешествие, так как (как можно предполагать) неясны цели и конечная точка такого плавания. Неудовлетворенность сущим для Шукшина не является еще веским основанием для перемены положения. Соединение, сдерживание двух стихий, двух культур, двух сущностей - это, по Шукшину, тяжелая миссия писателя в современном мире.

Вместе с тем, писатель явственно осознает временность такого сдерживания, неминуемость выбора; многочисленные знаки тире в данном тексте (этот пунктуационный знак является в поэтике прозаика наиболее частотным и художественно маркированным) в некотором роде могут быть символизированы в те сдерживающие нити (канаты, цепи), при помощи которых происходит поистине титаническая работа по сохранению единства русской культуры. ${ }^{4}$

В центре этой статьи будет находиться текст рабочей записи Василия Макаровича Шукшина:

Сто лет с лишним тянули наши титаны лямку Русской литературы. И вдруг канат лопнул; баржу понесло назад. Сколько же сил надо теперь, чтобы остановить ее, побороть течение и наладиться тащить снова. Сколько богатырей потребуется! Хорошо еще, если баржу-то не расшибет совсем о камни (Шукшин 1996: 231). ${ }^{5}$

В самых общих чертах некоторые ключевые идеи при комментировании данного текста выглядят так: шукшинская заметка обретает важную «укорененность» в «пространство» русской и - шире - мировой культуры, начиная с самых истоков европейской цивилизации, - античности. ${ }^{6}$ Как известно, титаны - в древнегреческой мифологии боги, дети Урана и Геи. Традиционна связь происхождения слова «титаны» с солнечным жаром и в целом с солнечной символикой (что почти неминуемо рецептирует пушкинское присутствие: «Солнце русской поэзии»). Титаны составили второе поколение Олимпийских богов и в свою очередь явились прародителями третьего младшего поколения олимпийцев (так называемых «детей титанов»). Таким образом, явственна генеалогия: старшие (отцы) - дети - младшие (внуки), что

${ }^{4}$ См. рабочую запись: «Надо совершенно спокойно - без чванства и высокомерия - сказать: у России свой путь. Путь тяжкий, трагический, но не безысходный в конце концов. Гордиться нам пока нечем» (Шукшин 1996: 236).

${ }^{5}$ Некоторые аспекты этого текста уже были проанализированы (ГлушАков 2011).

${ }^{6}$ Мы намеренно не рассматриваем большой пласт мотивности погибающего в бурю корабля в греческой и римской литературе, так как для не владевшего древними языками Шукшина этот пласт остался, видимо, неактуализированным. Укажем только на потенциально возможные источники, в частности, переводы, сделанные классиками русской поэзии. Из наиболее яркого контекста см., например, перевод А. Фетом Четырнадцатой оды Горация со значимыми для нашей темы образами: «Канаты лопнули и остов килем старым / Не в силах более бороться с морем ярым! / Ни славным именем, ни родом издавна, / Дочь гордая лесов, понтийская сосна, / Богов защитников в бедах не умолила: / В богах защиты нет и лопнули ветрила» (ФЕТ 2004: 570). 
сближает комментируемую рабочую запись с дневниковой заметкой о «родственном» понимании истории русской литературы. ${ }^{7}$

Вместе с тем, выражение, примененное к «титанам», - «тянуть лямку» привносит в текст новое значение: лямку на Руси традиционно тянули бурлаки, а также (согласно В. И. Далю) пушкари, которые перевозили пушки (военная семантика тут значима, так как «лямкой» называется и ремень солдатской сумы). Тянуть лямку - значит выполнять тяжелую работу, во многом, нечеловеческую (заменяя собой тягловых животных, например); но и - защищать родину, выполнять свой долг. Одновременно тут заложены и ассоциативные потенции: «сто лет... тянули лямку», то есть очень долго, без отдыха, с огромным напряжением и отдачей всех сил; «смысл» этой деятельности, по-видимому, заключался в достижении некой конечной точки, «экзистенциальной удовлетворенности» и завершенности; невозможность подобной завершенности прочитывается не без коннотаций мифа о Сизифе, причем как в его античном изводе, так и версии А. Камю. ${ }^{8}$

Русская литература (с заглавной буквы, то есть сакрализовывая это понятие, вспомним, например, выражение «святая русская литература» Т. Манна) непосредственно отождествляется с баржей/кораблем, прозрачным христианским символом Церкви. ${ }^{9}$ Узнаваемая культурная метафора Церковькорабль подкрепляется символикой человек-корабль (кораблик) в океанеморе житейском (вспомним главных греческих титанов: Океан - пространство, Кронос - время). Корабль отображает саму человеческую жизнь, а «конечный пункт» плавания - Жизнь вечную. Рисуемая картина катастрофы, катаклизма, ${ }^{10}$ регрессии («баржу понесло назад») сопрягается с уже упомя-

${ }^{7}$ «Патриарх литературы русской - Лев Толстой. Это - Казбек или что там? - самое высокое. В общем, отец. Пушкин - сын, Лермонтов - внучек, Белинский, Некрасов, Добролюбов, Чернышевский - племянники. Есенин - незаконнорожденный сын. Все, что дальше, - воришки, которые залезли в графский сад за яблоками. Их поймали, высекли, и они стали петь в хоpe - на клиросе. Достоевский и Чехов - мелкопоместные, достаточно самолюбивые соседи. Были еще: Глеб и Николай Успенские, Решетников, Лесков, Слепцов, Горбунов, Писемский, Писарев - это разночинцы» (Шукшин 1996: 230).

${ }^{8}$ См. свидетельство Р. Григорьевой о Шукшине в период учебы во ВГИКе: «Он был такой хитроватый в этом смысле человек и всегда любил ввести вас в заблуждение, любил, что называется, попридуриваться. Говорил, например: „Камю? А это кто такой?“ Хотя знал, разумеется, прекрасно» (цит. по Куляпин 2005: 5). Джон Гивенс обратил внимание на тему «Шукшин и экзистенциалисты» (и Камю, в частности) в работе «Особенности реализации экзистенциалистских идей в прозе В. Шукшина» (ГивЕНС 1992: 14). См. скептический взгляд на тему (РАЗУВАЛОВА 2015: 102-103).

${ }^{9}$ Ср. также у Б. Л. Пастернака: «Ко Мне на суд, как баржи каравана, / Столетья поплывут из темноты» («Гефсиманский сад»).

${ }^{10}$ Нельзя исключать и определенных неявных по семантике, но цитатных, а потому достаточно устойчивых параллелей с известными строками из В. Маяковского: «Любовная лодка разбилась о быт» и знаменитый Пароход Современности, с которого, как Разин персидскую княжну, необходимо «бросить» Пушкина и прочих (в том же манифесте прозрачная метафора: «Стоять на глыбе слова „мы“ среди моря свиста и негодования»). Также у Розанова: «„Пароход идет“ писательства - идет при горе, несчастии, муках души... Все „идет“ и „идет“... Корректуры, рукописи...» (РозАнов 1989: 424). 
нутой рабочей записью «Патриарх литературы русской...», с ее недвусмысленной реализованной метафорой изгнания из рая («сад с яблоками» и изгнание из него с принуждением «петь в хоре [церковном] - на клиросе»). Вместе с тем, возможно и прочтение: «вселенский потоп» ${ }^{11}$ (равно как и разрушение Вавилонской башни, смешения языков и потери единой коммуникации - темы центральной для Шукшина). Тут же возникшая метафора «побороть течение», неминуемо для русской культуры преобразующаяся в «против течения». Выражение «остановить ее» (то есть понесшую назад баржу) может прочитываться и в смещенных векторах: движение идет не только назад, но и вниз, то есть это падение (как реализация библейского грехопадения). Тут значим, безусловно, стихотворный текст А. К. Толстого «Против течения» (1867 г.) с прямыми евангельскими аллюзиями, темой художникамечтателя перед испытанием «нового времени» и рефреном «Дружно гребите, во имя прекрасного, / Против течения!» (Толстой 1984: 107). ${ }^{12}$

Образы богатырей, прочитываемых в ряде шукшинских контекстов как былинные герои («родственные» греческим титанам), в этой конкретной рабочей записи получают и потенциальное лермонтовское прочтение («богатыри не вы»), подкрепляющее уже отмеченное оппозиционирование «старшие - младшие» (которым досталась «плохая доля»). Именно «младшим» предстоит «тащить» лямку снова, преодолевая опасность «расшибиться» о камни (символика «камня», при всей ее многовариантности, непременно включает компонент «надежности, вечности и неуничтожимости»).

Знаменательно, что в шукшинской публицистике находимо не просто само интересующее нас словоупотребление («титаны-классики»), но развертывается последовательная мифологема поступательного движения вперед (или - как вариант - вверх) некой сплоченной вне времени группы русских писателей, которые в некотором смысле проделывают «смертельный номер», рискуют своей и общественной гибелью, но обладают гигантскими потенциями и верой в свое дело:

11 «Допотопность» баржи отмечена (с примером из Чехова: «допотопное животное») (см. КожЕВникОВА-ПЕТРОВА 2010: 261). Также см. у писателя, чрезвычайно повлиявшего на поэтику Шукшина: «Возвращаясь вечером с Ярмарки, я останавливался на горе, у стены кремля, и смотрел, как за Волгой опускается солнце, текут в небесах огненные реки, багровеет и синеет земная, любимая река. Иногда в такие минуты вся земля казалась огромной арестантской баржей; она похожа на свинью, и ее лениво тащит куда-то невидимый пароход» (М. Горький: В людях).

${ }^{12}$ О сущности этой поэтической формулы в мировоззрении Толстого см. Эткинд 2005: 492-505. Отметим также потенциальную связь императивных конструкций стихотворения Толстого и «олимпийской темы» и мотивности безнадежной борьбы (о ее присутствии в шукшинском тексте см. выше), заявленной в стихотворении Ф. Тютчева «Два голоса»: «Мужайтесь, о други, боритесь прилежно, / Хоть бой и неравен, борьба безнадежна!» (Тютчев 1966: 129). Ср. также «Две Троицы. Разин Напротив» В. Хлебникова: «На гордом уструге „нет-единицы“ плыть по душе Разина по широким волнам, будто по широкой реке... править челн поперек волне, поперек течению. [...] ...призрачный уструг „нет-единицы“ тихо плывет по реке Разина поперек естественного течения природы времени его Я» (ХлЕБников 1986: 567). О присутствии хлебниковского пласта в поэтике Шукшина см. ГлушАКов 2014. 
Как же мы должны быть благодарны им - всей силой души, по-сыновьи, как дороги они всякому живому сердцу, эти наши титаны-классики. Какой головокружительной, опасной кручей шли они. И вся их жизнь - путь в неведомое. И постоянная отчаянная борьба с могучим гадом - мещанином. Как нужны они, мощные, мудрые, добрые, озабоченные судьбой народа, - Пушкин, Толстой, Гоголь, Достоевский, Чехов... (Шукшин 1996: 50).

Здесь прозрачны змееборческие аллюзии, которые маркируют текст во вневременном и мифологическом плане, но, вместе с тем, вполне прозрачный тираноборческий мотив, недаром в процитированном фрагменте «Монолога на лестнице» (символический смысл этого названия совершенно очевиден) Шукшин говорит о Тени отца Гамлета, непосредственно сопрягая этот образ с образами писателей-классиков, чья роль в жизни современного человека столь же эфемерна, неочевидна (с обывательской точки зрения), но необходима в качестве «вечного напоминания» о ценностях культуры. Одновременно, потенциальное значение здесь приобретает стихотворение Тютчева «Наполеон» с его аллегорической картиной встающего в ночи почившего «тревожного духа», который ушел из реального мира в силу случившейся с ним катастрофы:

Он гордо плыл - презритель волн -

Но о подводный веры камень

В цепы разбился утлый челн.

(Тютчев 1989: 274) ${ }^{13}$

Образ «лопнувшего каната», связующей нити, скрепляющего звена может быть аллюзорно прочитан и как пушкинская «златая цепь», и как некрасовский образ из «Кому на Руси жить хорошо»: «Порвалась цепь великая, / Порвалась - расскочилася»; ${ }^{14}$ однако образ, возможно, дополнен и звуковой нюансировкой: «лопнувший натянутый канат» - это отсылка к знаменитой аудиальной метафоре из чеховского «Вишневого сада» (вновь образ сада), «звуку лопнувшей струны», ${ }^{15}$ которая, в свою очередь, многими нитями свя-

13 Любопытно, что еще ранее, в пушкинском «К морю» сходный мотив возникает именно при обращении поэта к наполеоновской теме: «Смиренный парус рыбарей, / Твоею прихотью хранимый, / Скользит отважно средь зыбей: / Но ты взыграл, неодолимый, / И стая тонет кораблей» (Пушкин 1937: 331).

${ }^{14}$ Часть первая, глава пятая: «Помещик». Некрасовское присутствие может быть подкреплено и при обращении к «Последним элегиям»:

Пышна в разливе гордая река,

Плывут суда, колеблясь величаво [...]

Но тут же, опрокинутый волной,

Погибни челн - и кто его заметит?

(НЕКРАСОВ 1990: 249)

15 «Гаев (негромко, как бы декламируя). О природа, дивная, ты блещешь вечным сиянием, прекрасная и равнодушная, ты, которую мы называем матерью, сочетаешь в себе бытие и 
зана с культурными мифологемами мировой культуры: от «распалась связь времен!» и до «дальше - тишина» Шекспира.

Шекспировский контекст потенциально актуализируется самим образом пустившегося в плавание судна; в «Буре» находимы некоторые имплицитные параллели:

Корабль отважный, где, конечно, были

И честные и праведные люди,

Разбился в щепы. В сердце у меня

Звучит их вопль. Увы, они погибли!

Была бы я всесильным божеством,

Я море ввергла бы в земные недра

Скорей, чем поглотить ему дала бы

Корабль с несчастными людьми. ${ }^{16}$

Мотив водного пути на лодке (корабле) появляется у Шукшина как концентрированный символ духовных устремлений, сердечных порывов, как аллегория движения к цели, преодоления препятствий; как метафора не только пространственная, но и временная («течение времени», державинская «река

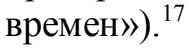

Нельзя исключать, что этот мотив использован Шукшиным не без влияния соответствующих страниц «Детей солнца» Максима Горького, в частности, того эпизода, в котором Елена Николаевна Протасова делится с присутствующими собственными «грезами»:

смерть, ты живишь и разрушаешь... [...] Вдруг раздался отдаленный звук, точно с неба, звук лопнувщей струны, замирающий, печальный» (Действие второе); ср.: «Слыхал ли в сумраке глубоком / Воздушной арфы легкий звон, / Когда полуночь, ненароком, / Дремавших струн встревожит сон?.. // То потрясающие звуки, / То замирающие вдруг... / Как бы последний ропот муки, / В них отозвавшися, потух!» (Тютчев 1989: 91). Чеховское присутствие потенциально можно обнаружить в таком эпизоде из «сахалинского путешествия»: «Когда он возвращался обратно через Индию на пароходе „Петербург“ и в Китайском море его захватил тайфун, причем пароход шел вовсе без груза и его кренило на 45 градусов, к брату Антону подошел командир „Петербурга“ капитан Гутан и посоветовал ему все время держать в кармане наготове револьвер, чтобы успеть покончить с собой, когда пароход пойдет ко дну. Этот револьвер теперь хранится в качестве экспоната в Чеховском музее в Ялте. Другой случай встреча с французским пароходом, севшим на мель. „Петербург“ по необходимости должен был остановиться и подать ему помощь. Спустили проволочный канат - перлень, соединили его с пострадавшим судном, и когда стали тащить, канат лопнул пополам. Его связали, прицепили снова, и французский пароход был спасен. Всю дальнейшую дорогу французы, следовавшие позади, кричали „Vive la Russie!“ и играли русский гимн; и затем оба парохода разошлись, каждый поплыл своей дорогой» (САХАРОВА 1990: 280-281).

${ }_{17}^{16}$ Первый акт, вторая сцена, слова Миранды.

${ }^{17}$ Стоит напомнить, что будущий писатель служил матросом на Балтийском флоте, дебютировал в кино в образе матроса, в сценарии и фильме «Печки-лавочки» герой устремляется в длинное путешествие к морю, а кончина Шукшина 2 октября 1974 года последовала на борту теплохода «Дунай». Знаменательно, что водные пути сейчас бороздит самоходная баржа «Василий Шукшин». 
Вы знаете, порой мне грезится такое полотно: среди безграничного моря - идет корабль; его жадно обнимают зеленые, гневные волны; а на носу его и у бортов стоят какие-то крепкие, мощные люди... Просто - стоят люди, - все такие открытые, бодрые лица, - и, гордо улыбаясь, смотрят далеко вперед, готовые спокойно погибнуть по пути к своей цели... Вот и вся картина! (Горький 1970: 331).

Возвратимся, однако, к комментированию пушкинских контекстов рабочей записи Шукшина: как представляется, пушкинское присутствие здесь в некотором роде обертонно, организовано по принципу «эхо», когда различные образы, мотивы и ассоциации выполняют роль смысловых узлов текста.

Так, в стихотворении «Арион» (1827) рисуется явственно аллегорическая картина движения к определенной цели на морском судне и последовавшей внезапной катастрофы:

...Вдруг лоно волн
Измял с налету вихорь шумный...
Погиб и кормщик и пловец! -
Лишь я, таинственный певец,
На берег выброшен грозою,
Я гимны прежние пою
И ризу влажную мою
Сушу на солнце под скалою.

(Пушкин 1948: 58)

Наконец, в стихотворении «Осень» («Октябрь уж наступил...») (1833) помимо прозрачной образности готового к отплытию корабля (то есть в некоторой степени той ситуации, которая предмествовала конечному акту этого трагически завершившегося символического путешествия), в завершающих строках этого неоконченного текста формулируется одна из ряда суггестивно-мировоззренческих формул русской литературной культуры (наряду с подобными же вопросами Герцена «Кто виноват?» и Чернышевского «Что делать?»- в веке XIX, а затем вопросом Шукшина «Что же с нами происходит?»):

XI

И мысли в голове волнуются в отваге,

И рифмы легкие навстречу им бегут,

И пальцы просятся к перу, перо к бумаге.

Минута - и стихи свободно потекут.

Так дремлет недвижим корабль в недвижной влаге,

Но чу! - матросы вдруг кидаются, ползут

Вверх, вниз - и паруса надулись, ветра полны;

Громада двинулась и рассекает волны.

XII

Плывет. Куда ж нам плыть?

(Пушкин 1948: 318-321) 
Наконец, важным представляется указать и на весьма близкое шукшинскому личное мироощущение: в записях Н. А. Клюева (заметим сходность жанровых установок двух писателей) находимы как собственно рассматриваемые предикаты, так и заявлена мотивность личной связи автора с происходящим, судьбоносности подобного соприкосновения:

Чувствую, что я, как баржа пшеничная, нагружен народным словесным бисером. И тяжело мне подчас, распирает певческий груз мои обочины, и плыву я, как баржа по русскому Ефрату - Волге в море Хвалынское, в персидское царство, в бирюзовый камень. Судьба моя - стать столпом в храме Бога моего и уже не выйти из него, пока не исполнится все (Клюев 2003: 66). ${ }^{18}$

Наш комментарий почти неминуемо балансирует на грани очевидного и гипотетического, причем даже выявление, казалось бы, совершенно определенных претекстов многое добавляет и к предполагаемому прочтению. Например, в предыдущих параллелях нами совершенно не рассматривались синхронные времени формирования Шукшина-читателя контексты, казалось бы, совершенно банальные и малоинтересные, число коих можно легко множить. Возьмем для наглядности выходившие в 40-50-е годы многочисленные и многотиражные, бывшие почти во всякой библиотеке и использовавшиеся на уроках литературы в школе, сборники типа «писатель в критике». Открывались такие книги пространной установочной статьей, которую условно можно назвать «Вот как надо понимать», автор которой «расставлял акценты» и поправлял слишком вольных интерпретаторов. Вполне вероятно, что клишированный язык, всезнающая интонация такого рода статей, часто конспектировавшихся учащимися, некоторым образом мог повлиять (и потом отозваться) на, в первую очередь, словоупотребление (но никак, конечно, не на семантику самой рабочей записи) Шукшина. Там, возможно, найдено было Шукшиным слово «титаны», в составе словосочетания титаны русской литературы: «Восторженно о Гоголе писали такие титаны русской литературы и критики, как Пушкин, Белинский, Герцен, Некрасов, Чернышевский, Добролюбов, Гончаров, Тургенев, Островский, Л. Толстой, Короленко» (Поляков 1953: 11). Между тем, более чем неверно (и даже смешно) было бы предполагать, что в этой цитате М. Полякова «обнаруживается» источник одного из образов шукшинского текста; перед нами не более чем гипотетическая «отправная точка» для сложных построений писателя, «клишированный шум» официозной идеологии, которой, как всякий другой, был Шукшин. ${ }^{19}$

${ }^{18}$ См. также: «у Чулкова слова - пароходище, пыхтящий колесами, выволакивающий на буксире от него отставшую лодочку; жест Мейерхольда - моторная лодка, срывающая с места: баржи идей» (БЕлый 1990: 62).

${ }^{19}$ См.: «К концу 60-х годов в институте зачастили собрания; учились говорить доморощенные интеллектуалы, в основном москвичи... Выступал на собраниях всегда и Шукшин, он получал слово „от народа“. На трибуне он появлялся в гимнастерке (после-то признавался: „Ничего больше и не было“), отбивая шаг сапогами, раскачиваясь. Слова выговаривал четко. Говорил он, как мне казалось, опираясь на текущие лозунги...» (БЕЛОВ-ЗАБОлоцкий 2002: 89). 
Гораздо интересней проследить за «неявными» корнями поэтики рабочей записи. Здесь чрезвычайно далекие и маловероятные отзвуки из уже обнаруженного шекспировского пласта могут быть дополнены образом челна, разбитого надвое грозой (из «Генриха VI»), - с актуализацией конечных координат как неизбежно трагических: «Там - путь мой к гибели» (Сеффолк) и «А здесь - путь мой» (Королева Маргарита) (Шекспир 1957: 265).

Это идет вразрез с шукшинским пониманием, если присмотреться, совершенно определенным - для писателя устремившаяся вниз по течению баржа непременно будет остановлена, ее гибель будет предотвращена, пусть и огромными усилиями и жертвами. Даже если «баржу расшибет совсем о камни», то и тогда еще не все потеряно. Здесь в прямой диалог с Шукшиным вступает Н. М. Рубцов: «Лодка на речной мели / Скоро догниет совсем. / [...] Завтра у меня под ней / Будет хлопотливый день! / [...] Буду до ночной звезды / Лодку мастерить себе...» (РуБцов 1990: 23).

Однако трагическая интенция не преодолевается, проходя круги испытаний и прельщений (о дантовском - а от него к «Одиссее» - подтексте рабочей записи необходимо будет сказать в совершенно отдельной заметке ${ }^{20}$ ). В стихотворении Ивана Козлова «Разбитый корабль» (1832) явлена конечная и непоправимая (а значит - уводящзя прочь от Шукшина) картина:

День гаснул в зареве румяном, -

И я, в смятеньи дум моих, Бродил на береге песчаном,

Внимая ропот волн морских.

И я увидел меж песками

Корабль разбитый погружен;

Он в бурю шумными волнами

На дикий берег занесен, -

И влага мхом давно одела

Глубоких скважин пустоты;

${ }^{20}$ См., например:

Сменилось плачем наше торжество:

От новых стран поднялся вихрь, с налета

Ударил в судно, повернул его

Три раза в быстрине водоворота;

Корма взметнулась на четвертый раз,

Нос канул книзу, как назначил Кто-то,

И море, хлынув, поглотило нас.

(Данте: «Ад». Песнь двадцать шестая)

См. комментарий К. Каннегисера: «в основе этого дивного рассказа об Улиссе лежит порицание человеческаго высокомерия, тех хитросплетений ума, той изобретательности и предприимчивости, которые устремляют деятельность человека за пределы возможного [...] Потому Улисса, как он выведен здесь, можно сравнить с древними Титанами или Кентаврами, дерзнувшими на брань с самыми богами...» (Ад 1855: 219). 
Уже трава в них зеленела,

Уже являл моя цветы.

Стремим грозой в утес прибрежный,

Откуда и куда он плыл?

Кто с ним в час бури безнадежной

Его крушенье разделил?

Утес и волны, все молчало,

Все мрак в уделе роковом, -

Лишь солнце вечера играло

Над ним, забытым мертвецом.

(Козлов 1948: 122)

Какой погибший «корабль» видит лирический герой Козлова, определить не сложно, - это «затопленный» еще в 1825 году «корабль испанский» из пушкинской «Сцены из Фауста»:

$\Phi$ aycm

Что там белеет? говори.

Мефистофель

Корабль испанский трехмачтовый,

Пристать в Голландию готовый:

На нем мерзавцев сотни три,

Две обезьяны, бочки злата,

Да груз богатый шоколата,

Да модная болезнь: она

Недавно вам подарена.

Фaycm

Все утопить.

Мефистофель

Сейчас.

(Пушкин 1977a: 256-257)

Конечно, это не «баржа», которую тянули титаны Русской литературы, а одна из ипостасей Корабля дураков, позднее - Пьяного корабля, которому не суждено было стать Летучим Голландием, а разве только «Титаником», о гибели которого Александр Блок записал в своих рабочих записях так поразившие многих строки: «Гибель Titanic'a, вчера обрадовавшая меня несказанно (есть еще океан). Бесконечно пусто и тяжело» (Блок 1963: 139). ${ }^{21}$

Но кое-что этот образ может предложить: пусть и с грешниками, но корабль был затоплен Мефистофелем, темной потусторонней силой. Не она ли

${ }^{21} \mathrm{Cp}$. также с образом вставшей на большой мели барки из блоковского стихотворения «Барка жизни встала...» (1904). 
«приложила руку» и к лопнувшему канату сорвавшейся баржи? («Вот умрет Толстой - все к черту пойдет», как сказал некогда Чехов, предрекая один из возможных «разрывов» нашего связующего каната.)

Как говорил Петруша Верховенский в «Бесах» Достоевского, «и взволнуется море, и рухнет балаган...» (Достоввский 2015: 505). В «Бесах» же находим заветную шукшинскую мотивность - разинскую, поданную там неожиданно в речах того же Верховенского: «Мы, знаете, сядем в ладью, веселки кленовые, паруса шелковые, на корме сидит красна девица, свет Лизавета Николаевна... или как там у них, черт, поется в этой песне...» (Достоввский 2015: 462), - то есть разинской песне. Заметим, что в третий раз в этом контексте звучит имя черта (у Достоевского - «чорта»), «актора» будущей трагедии. Подчеркнем также, что ладья в речах Петра Верховенского уже предназначена на слом, гибель: «Какая вы „ладья“, старая вы, дырявая дровяная барка на слом!» («Мы на горе всем буржуям мировой пожар раздуем» - не из этих ли «дровишек»?). Примечательно, что Петр (= камень) с такой ненавистью говорит о деревянной барке (= деревянной Руси).

«Сто лет с лишним...». И вот в «Медном всаднике»:

На берегу пустынных волн

Стоял он, дум великих полн,

И вдаль глядел. Пред ним широко

Река неслася; бедный челн

По ней стремился одиноко. [...]

Прошло сто лет, и юный град,

Полнощных стран краса и диво,

Из тьмы лесов, из топи блат

Вознесся пышно, горделиво;

Где прежде финский рыболов,

Печальный пасынок природы,

Один у низких берегов

Бросал в неведомые воды

Свой ветхой невод, ныне там

По оживленным берегам

Громады стройные теснятся

Дворцов и башен; корабли

Толпой со всех концов земли

К богатым пристаням стремятся;

В гранит оделася Нева;

Мосты повисли над водами;

Темно-зелеными садами

Ее покрылись острова,

И перед младшею столицей

Померкла старая Москва,

Как перед новою царицей

Порфироносная вдова.

(Пушкин 1977b: 274-275) 
Переодевшийся из деревянной одежки в гранитную город так возгордился, как тот шукшинский герой:

Человек купил, наконец, дубленку, долгожданную, желаннейшую дубленку... И к вечеру стал вдруг (в дубленке), стал таким умным, сведущим, начитанным, информированным, свободомыслящим, резким... И сказал, сплюнув: «Достоевский - это не пророк» (Шукшин 1996: 193).

Вопрос без ответа на клубок противоречий и проблем дан в стихотворении иеромонаха Романа:

Ax, как я долго плыл без Кормчего и весел,

Болталась по волнам разбитая ладья.

Ни щепки под рукой, и якоря не бросить,

До дна, наверняка, достать мог только я. [...]

Молился ли тогда? Наверное, не помню.

Глядел за горизонт - бездумно, просто так.

Но парусник пришел и я тогда не помер.

Пристанем ли теперь? ...И снег, и шторм, и мрак.

(РомAн 2005: 34)

Сквозь столетие горя и трагедии проходит путь сорвавшейся баржи; ее близкими «родственниками», в некотором смысле, являются и требующая своей жертвы железная дорога, и гоголевская тройка, несущаяся по ей одной ведомым путям и не дающая никакого ответа; о всех кораблях, ушедших в море, поет блоковская девушка; маячит заблудившийся трамвай и безразличные ко всему, вне времени, «...тихо идут по Неве корабли».

\section{Литература}

Ад 1855 = Ад Данта Алигьери. Москва, 1855 .

БЕЛОВ-ЗАБОЛОцкий 2002 = БЕЛОВ В., ЗАБОЛОцкий А. Тяжесть креста. Шукшин в кадре и за кадром. Москва, 2002.

БЕлый 1990 = БЕлый А. Между двух революиий. Воспоминания. Москва, 1990.

Блок 1963 = Блок А. А. Собрание сочинений в 8 томах. Т. 7. Москва-Ленинград, 1963.

ГивенС 1992 = ГивенС Д. Особенности реализации экзистенциалистских идей в прозе В. Шукшина. В кн.: Шукшин - философ, историк, художник. Вып. 3. Барнаул, 1992. 11-36.

ГлушАКов $2011=$ ГлушАКов П. С. К изучению семантики художественного текста Василия Шукшина. Slavia 81 (2012): 277-282.

ГлушАКОВ $2014=$ = ГушАКОВ П. С. «Други милые, нечем кричать». О поэтике Василия Шукшина. Литературная учеба 2014/4: 147-173.

Горький $1970=$ Горький М. Полное собрание сочинений. Т. 7. Москва, 1970.

Достоевский 2015 = Достоввский Ф. М. Бесы. Т. 1. Москва-Берлин, 2015.

Клюев 2003 = Клюев Н. Словесное древо. Санкт-Петербург, 2003. 
КОЖЕВНИКОВА-ПЕТРОВА $2010=$ КОЖЕВНИКовА Н. А., ПЕТРОВА З. Ю. Материаль к словарю метафор и сравнений русской литературы XIX-XX вв. Вып. 2. Звери, насекомыле, рыбыл, змеи. Москва, 2010.

Козлов 1948 = Козлов И. Стихотворения. Ленинград, 1948.

Куляпин 2005 = Куляпин А. И. Творчество В. М. Шукиина. От мимезиса к симеозису. Барнаул, 2005.

НЕКРАСОВ 1990 = НЕКРАСов Н. А. Собрание сочинений в 4 томах. Т. 1. Москва, 1990.

Поляков 1953 = Поляков М. Гоголь в оценке русской критики. В кн.: Н. В. Гоголь в русской критике. Москва, 1953. 9-129.

Пушкин 1937 = Пушкин А. С. Полное собрание сочинений в 16 томах. Т. 2. МоскваЛенинград, 1937.

Пушкин $1948=$ Пушкин А. С. Полное собрание сочинений в 16 томах. Т. 3. Кн. 1. Москва-Ленинград, 1948.

Пушкин 1977a = Пушкин А. С. Полное собрание сочинений в 10 томах. Т. 2. Москва, 1977.

Пушкин $1977 \mathrm{~b}=$ Пушкин А. С. Полное собрание сочинений в 10 томах. Т. 4. Москва, 1977.

РАЗУВАЛОВА 2015 = РАЗУВАЛОВА А. Писатели-«деревенщики». Литература и консервативная идеология 1970-х годов. Москва, 2015.

РозАнов 1989 = РозАнов В. В. Мысли о литературе. Москва, 1989.

Роман 2005 = Роман Иеромонах: Внимая Божьему веленью. Стихи. Духовные песнопения. Минск, 2005.

РуБцОв 1990 = РуБцов Н. М. Видения на холме. Москва, 1990.

СаХАРОвА 1990 = САХАРОвА Е. М. (сост.) Вокруг Чехова. Москва, 1990.

Толстой 1984 = Толстой А. К. Полное собрание стихотворений в 2 томах. Т. 1. Москва, 1984.

ТюТчев 1966 = ТютЧЕВ Ф. И. Лирика в 2 томах. Т. 1. Москва, 1966.

Тютчев 1989 = Тютчев Ф. И. Стихотворения. Москва, 1989.

ФЕт 2004 = ФЕТ А. А. Сочинения и письма в 20 томах. Т. 2. Санкт-Петербург, 2004.

ХлЕБников 1986 = ХлЕьников Велимир: Творения. Москва, 1986.

ШЕкСпиР 1957 = ШЕкСпиР У. Полное собрание сочинений в 8 томах. Т. 1. Москва, 1957.

Шукшин 1996 = Шукшин В. М. Собрание сочинений в 5 томах. Т. 5. Москва, 1996.

Эткинд 2005 = Эткинд Е. Г. Психопоэтика. «Внутренний человек» и внешняя речь. Статьи и исследования. Санкт-Петербург, 2005. 